\title{
Evaluation on the Effects of a New Integrated Health Management Service Model on People With Risk Factors for Dyslipidemia
}

Rui Zhang

China Medical University

Shuang Wang

China Medical University

Yi-Ni He

China Medical University

Bin Wu

China Medical University

Ying Wu

China Medical University

Kai Yu

China Medical University

Dian-Jun Qi

China Medical University

Xiao-Song Yu ( $\sim$ xsyu@cmu.edu.cn )

China Medical University https://orcid.org/0000-0001-6892-8049

Research article

Keywords: Dyslipidemia, Blood lipid, General medicine, Integrated medicine

Posted Date: August 12th, 2020

DOl: https://doi.org/10.21203/rs.3.rs-48897/v1

License: (9) (1) This work is licensed under a Creative Commons Attribution 4.0 International License. Read Full License 


\section{Abstract}

Background: Dyslipidemia is a factor affecting the occurrence and development of many chronic diseases. With its prevalence increasing year by year, dyslipidemia has caused a huge burden of disease and economy in China and even the world. Appropriate health management is imperative for people with risk factors for dyslipidemia. However, the traditional health management service models mainly focus on the population with chronic diseases. Therefore, we need to establish new models of health management services to more appropriately manage people with risk factors for dyslipidemia.

Methods: Among the 5 administrative districts with a population of more than 100,000 in Shenyang, 23 community health service centers with an average daily outpatient number of more than 50 were selected. A total of 5,032 subjects with risk factors for dyslipidemia who met the inclusion criteria were included in this study. Using prospective cohort study methods. The subjects were followed up for 24 months. They were randomly divided into control group and test group , and received integration of general practice and personalized disease prevention in health management (IGPDP) or traditional health management services, respectively. We analyzed and compared changes in disease prevention, health protection, and health promotion between the two groups at baseline, 12 months after the intervention, and 24 months after the intervention.

Results: In terms of disease prevention, we found that after the intervention, participants' behavioral risk factors (smoking, diet, sedentary) improved and their health literacy improved. In terms of health protection, we observed a decrease in BMI (biological risk factor), a gradual improvement in blood lipid levels, and an overall increase in quality of life scores. In terms of health promotion, after the intervention, the proportion of the subjects willing to accept the contracted services of general practitioners increased.

Conclusion: IGPDP can effectively cultivate healthy lifestyle of subjects, improve health literacy, reduce biological risk factors, reduce the risk of dyslipidemia, and improve subjects' quality of life. IGPDP is conducive to improving the service quality of general practitioners, the trust of the general public, and facilitating the establishment of a hierarchical medical system.

\section{Background}

Dyslipidemia usually refers to abnormal blood lipid metabolism in the human body. According to the diagnostic criteria of the revised guidelines for the prevention and treatment of dyslipidemia in Chinese adults newly formulated in 2016, one of the abnormality in serum triglyceride (TG), total cholesterol (TC), serum low-density lipoprotein cholesterol (LDL-C) and serum high-density lipoprotein cholesterol (HDLC) can be diagnosed as dyslipidemia [1]. In the past 30 years, the prevalence of dyslipidemia has been increasing year by year, and dyslipidemia has become a public health concern [2]. To solve this problem fundamentally, it is necessary to implement sensible health management for people with risk factors for dyslipidemia.

Health management service model is a relatively new health management model proposed in recent years. Different from the general specialized medical service model, it mainly targets the chronic diseases (including hypertension, diabetes, etc.) whose prevalence rate is increasing year by year [3-5]. In the past 30 years, in order to solve the burden of chronic diseases, health management has developed rapidly in developed countries. However, it has just started in China, gradually attracting the attention of all parties, mainly in the form of physical examination [6-10]. Although some achievements have been made in the application of the traditional health management model in China, there are still many problems to be solved, such as: the complete medical service model has not been formed, and the personalization is not good, etc. In addition, the research on the traditional health management service model mainly focuses on the population with chronic diseases, such as hypertension and diabetes, and pays little attention to the population with risk factors for chronic diseases. In order to solve the above drawbacks, this study applied the model (integration of general practice and personalized disease prevention in health management, IGPDP) established in our previous studies that combines general practice with the personalized disease prevention. IGPDP is an evidence-based health management service model that establishes basing on Chinese the traditional health management service model and absorbing the foreign practice experience of general practitioners. It incorporates general practice and personalized disease prevention in the health management service framework, and provides early screening, early warning, risk factor intervention and long-term follow-up services for major chronic diseases and their risks in relatively healthy people (i.e. people with risk factors for dyslipidemia in this study). The IGPDP emphasizes that general practitioners and their teams provide subjects with people-oriented, personalized, continuous, comprehensive, and active health management services. The aim is to provide a systematic service program for health managers to help subjects improve self-efficacy, promote behavior change, and improve health outcomes (Fig. 1).

Fig. 1 Health management cycle

In order to explore the difference in the application value and effect of IGPDP and traditional health management model in people with risk factors for dyslipidemia, we randomly assigned 5032 subjects in this study to the control group (traditional health management model group) 
and the test group (IGPDP group), and compared the differences between the two groups in three aspects of disease prevention, health protection and health promotion at different time points according to the pre-designed evaluation index system.

\section{Methods}

\section{General Information}

We established the IGPDP prospective study cohort and completed a 24-month. Random cluster sampling and random sampling were used for sampling. Those who met the inclusion criteria in each community health service center within one month were included in this study in turn, until the number reached the requirements.

Sampling steps: Firstly, cluster sampling was carried out for the community health service centers in the five administrative regions of Shenyang with a population of more than 100,000 and an average daily outpatient volume of more than 50 . Then, a certain number of community health service centers were randomly selected in each administrative region to be included in this study. Finally, the subjects were randomly divided into a control group or a test group as shown in the table below (Table 1). The Medical Ethical Commission of the China Medical University approved this study. The consent we obtained from study participants was written.

Table 1 Source and grouping of research samples

\section{Inclusion and exclusion criteria}

A prospective cohort study was carried out, and the inclusion and exclusion criteria as shown in the table below (Table 2).

Table 2 Inclusion and exclusion criteria

\section{Intervention methods}

IGPDP was used in the test group and traditional health management service model was used in the control group. In the control group: carry out an annual physical examination according to the medical examination package for the subjects, provide group health consultation for the subjects, and coordinate specialist referral as required. In the test group, the one-year intervention cycle was divided into a two-month strengthening phase, a one-month consolidation phase and a nine-month stable phase (Fig. 2). According to the individual condition of the subjects, we made a health plan for them, and provide personalized diet and exercise guidance according to the plan. After a period of intervention, the health plan was modified or reformulated according to the changes in the subjects' health status. The implementation effect was evaluated by analyzing the subjects' questionnaire results and clinical indicator results at baseline, 12 months, and 24 months.

Fig. 2 Technology road map

\section{Evaluation index system}

We evaluated the effect of IGPDP from three aspects: "disease prevention", "health protection" and "health promotion". Results at baseline, 12 months after intervention, and 24 months after intervention were collected by measuring clinical indicators and questionnaires. Data were collected by trained investigators (Table 3 ).

Table 3 Evaluation index system

\section{Specific information of questionnaires}

Health risk assessment questionnaire

The questionnaire was used to collect the subjects' basic information, behavioral risk factors, biological risk factors and other related indicators. The questionnaire included the subjects' basic information, disease history, family history, tobacco use, alcohol consumption, daily diet and exercise, sleep quality, psychological status and living environment, as well as basic physical indicators (waist circumference, BMI, blood pressure, blood lipid, fasting blood glucose, etc.).

National Residents' Health Literacy Monitoring Questionnaire

The questionnaire was used to measure participants' health literacy. The questionnaire covers three dimensions: basic knowledge and concept, healthy lifestyle and behavior, and basic skills. It is specifically divided into six categories: health science concept, prevention and treatment of infectious diseases, prevention and treatment of chronic diseases, basic medical treatment, safety and first aid, and access to 
health information. The scoring standard of the questionnaire is 1 point for each question of judgment and single choice. Two points for each multiple-choice question. More than $80 \%$ of the accuracy is considered to have health literacy.

Health status SF-36 Questionnaire

The questionnaire was used to measure the quality of life of the subjects. It comprehensively measured the quality of life of the subjects from 8 aspects: physical enginery, physiological function, physical pain, general health, energy, social function, emotional function and mental health. In addition, it also included health change indicators to evaluate the overall changes in subjects' health status over the past year. According to the choice weight or score of SF-36 questionnaire, the total score of SF-36 is 145.

\section{Basic Health Service Demand Questionnaire}

This questionnaire is used to investigate the needs of community residents for basic medical and health services. The questionnaire included three aspects, basic medical and health service, general practitioner and community health service center. It provides a reference for improving the services of general practitioners and making them better meet the needs of the public.

\section{Statistical analysis}

Each monitoring and investigation in this study has gone through the process of data cleaning, data verification and standard database establishment. Epidata 3.1 software was used to establish a database. Logical error checking was conducted after data entry, and the outliers were returned to the original research institution for verification against the original questionnaire. Then, randomly select data and original data at a rate of $20 \%$ for verification. Finally, lock the database for statistical analysis. SPSS 22.0 software was used for statistical analysis of the data. The measurement data were described as mean \pm standard deviation, and rate was used to described the counting data. The ttest of two independent samples was used to compare the measurement data between the two groups, and the chi-square test was used to compare the rate. One-way analysis of variance was used to compare the measurement data among multiple groups. Test level $\mathrm{a}=0.05$.

\section{Results}

\section{General Characteristics of subjects}

The general characteristics of the test and control group subjects at baseline were shown in Table 4 . There was no statistically significant difference between the two groups in terms of general conditions and health indicators, indicating that the two groups were balanced and comparable at baseline.

The average age of the control group was $50.2 \pm 14.0$ years old, among which $56.8 \%$ were female, $71.3 \%$ were married, $36.1 \%$ had Junior college degree, $42.7 \%$ were retired, $83.4 \%$ were non-smokers, and $85.2 \%$ had never drunk. The average age of the test group was $53.8 \pm 14.9$ years old, of which $56.8 \%$ were female, $67.9 \%$ were married, $33.9 \%$ had received a Junior college education, $33.9 \%$ were retired, $76.1 \%$ had never smoked and $78.8 \%$ had never drunk.

Table 4 General Characteristics between the management and control groups at baseline

\section{Changes in behavioral risk factors before and after intervention in different groups}

In both control and test groups, the proportion of subjects who smoked, ate unhealthy diets and sat for long periods after the intervention decreased compared with those before the intervention, and the differences were statistically significant. The changes of behavioral risk factors before and after intervention in different groups are shown in table 5.

Table 5 Changes in behavioral risk factors before and after intervention in different study groups

\section{Changes in health literacy levels after intervention}

In the test group, the baseline health literacy level of subjects of different genders and ages was higher than that of the control group, except for the group aged 60-79 years, and the differences were statistically significant. After 12 months of intervention, except the test group aged 60-79 years, the health literacy level of subjects of different genders and different age groups all showed a downward trend, and the reasons for which need further analysis. After 24 months of intervention, the level of health literacy was generally improved, and the difference was 
statistically significant compared with that before the intervention. The health literacy level of the test group was still higher than that of the control group, and the difference between the two groups of subjects of different genders and different ages was statistically significant. Changes in health literacy levels in different groups after intervention are shown in Table 6.

Table 6 Changes in health literacy levels after intervention in different study groups

\section{BMI changes in obese people before and after intervention in different groups}

After the intervention, BMI of obese people in both the control group and the test group showed a decreasing trend, and the difference was statistically significant. BMI changes in obese people before and after intervention in different study groups are shown in Table 7

Table 7 Comparison of BMI levels in obese people in different study groups

\section{Changes of blood lipid levels in patients with dyslipidemia before and after intervention in different groups}

After the intervention, the TC, TG and LDL-C levels of the subjects showed a decreasing trend in both the control group and the test group. Except for the LDL-C level, the other differences were statistically significant. After intervention, HDL-C level increased slightly, with no statistically significant difference. Compared with the control group, there was no obvious advantage in the decrease of the test group. The changes of lipid levels in dyslipidemia patients before and after intervention in different groups are shown in table 8.

Table 8 Comparison of blood lipid levels in people with dyslipidemia in different study groups

\section{Changes in the total score of life quality assessment after intervention}

There was no statistically significant difference in the total score of life quality at baseline between the test group and the control group aged 18-44 years and 60-79 years. The total score of life quality in the test group was higher than that in the control group, and the difference was statistically significant. After 12 months of intervention, the total scores of life quality in different groups, genders and age groups showed a general trend of decline, and the difference was statistically significant compared with that before the intervention. The reasons need to be further analyzed. After 24 months of intervention, the total scores of life quality in different groups, genders and age groups showed an overall upward trend, and the differences were statistically significant compared with those before the intervention. Compared with the control group, the total increased extent of life quality was lower in the test group. The changes of the total score of life quality assessment in different intervention groups are shown in Table 9.

Table 9 Changes in total scores of quality of life assessment in different study group populations

\section{The proportion of subjects who were willing to accept general practitioners contract services after the intervention}

After 24 months, the proportion of people in different study groups, genders and age groups willing to receive general practitioners contract services was higher than that before the intervention. There were statistically significant differences before and after intervention in male group, female group, 18-44 years old group, 45-59 years old test group and 60-79 years old control group. The proportion of people willing to accept general practitioners contract services was slightly higher in the experimental group than in the control group. The comparison of the proportion of people willing to receive general practitioners contract services after intervention in different groups is shown in Table 10.

Table 10 Comparison of the proportion of people who are willing to accept general practitioners

\section{Discussion}

The baseline survey results showed that the prevalence of dyslipidemia in the test group and the control group was $70.7 \%$ and $76.6 \%$, respectively, which were both higher than the national average, suggesting that the study population had a heavy burden of dyslipidemia. 
After intervention, the TC, TG and LDL-C levels of patients with dyslipidemia decreased. In addition, the main health outcome indicators, quality of life and health literacy of the subjects all showed an increasing trend. Additionally, we used the proportion of subjects who were willing to accept general practitioners contract service to evaluate the utilization of primary care facilities. The results showed that the number of subjects in the test group who were willing to accept general practitioners contract service after the intervention showed an increasing trend compared with that before the intervention, and the increasing range was significantly higher than that in the control group. After the intervention, the satisfaction of the experimental group was also higher than that of the control group, indicating that IGPDP is conducive to promoting general practitioners contract service, improving the trust of the general public in doctors, and facilitating the establishment of a hierarchical medical system. We believe that IGPDP can effectively cultivate healthy lifestyle of subjects, improve health literacy, reduce biological risk factors, reduce the risk of dyslipidemia, and improve subjects' quality of life. In short, IGPDP is scientific in design and feasible in operation. From the current implementation effect, it is effective and better than the traditional health management model.

The traditional health management service model does not implement the new "health management path and implementation process of grassroots high-risk groups of chronic diseases", and does not establish a vertical collaboration platform between comprehensive departments of general hospitals and grassroots medical institutions. The subjects received follow-up and non-individualized health education at the community health service center. However, this service model is too simple to meet the needs of people with risk factors for dyslipidemia. The IGPDP provides health management services to selected high-risk groups, with the aim of achieving effective interaction between general practitioners, clients, patients, families and the community in health status assessment, self-management support, health management programme optimization and follow-up management. IGPDP adopts the contract service model of general practitioners, establishes a vertical cooperation platform between general hospitals and primary medical institutions, and some pilot institutions establishes a remote "Internet + " cooperation platform, so as to form a reasonable division of labor and management model between primary medical institutions and 3A hospitals and between general practitioners and experts. IGPDP trains primary-level general practitioners and their teams, provides convenient "two-way referral" channels for patients, and gradually forms a progressive diagnosis and treatment model of "initial diagnosis, two-way referral, rapid division and treatment, and linkage up and down". IGPDP can improve the service quality and utilization of health management, improve service target satisfaction and compliance, and help control the lipid level of high-risk population.

The IGPDP emphasizes that general practitioners and their teams provide subjects with people-oriented, personalized, continuous, comprehensive, and active health management services. Specifically, personalization is reflected in that researchers carry out personalized health counseling and health education services according to the differences of the subjects' own conditions, and formulate corresponding and specific health management plans for them and supervise their implementation. This model overcomes the shortcomings of the traditional health management model which ignores individual differences.

The continuity of IGPDP is reflected in the fact that its intervention process is a continuous dynamic process. We divided the entire intervention cycle into strengthening phase, consolidation phase and stable phase. During each phase of the intervention cycle, the subjects were followed steadily and continuously, and their health plans were monitored throughout. At the same time, we measured the health status of the subjects in stages, kept track of the changes in their health status, and timely adjusted the intervention intensity and improved the intervention plan according to the changing health status, so as to finally achieve the goal of improving the health status of the subjects.

The comprehensiveness of IGPDP is reflected in its diversified management methods. Different forms of health counseling and health education were given to the subjects, and health knowledge was popularized to the subjects, so as to help them master the prevention and treatment methods of dyslipidemia and other chronic diseases and improve their health literacy.

\section{Limitations}

Although IGPDP is scientific and effective, this model still has some drawbacks. Firstly, general practitioners play an irreplaceable role in IGPDP. However, the number of general practitioners in China is not enough to meet the requirements of implementing IGPDP on a large scale. Secondly, the development of a healthy lifestyle requires a long-term process. Although the IGPDP intervention improved the participants' lifestyle in the short term, there may be relapse after the intervention. Finally, this study only selected a part of indicators to be included in the evaluation system of this study, which could not be analyzed more comprehensively. More evaluation indicators can be included in future research to achieve a more comprehensive effect evaluation.

\section{Conclusion}

The purpose of constructing, implementing and evaluating the new health management model is to innovate the health management model, improve the ability, quality and effect of general practitioners to manage the population with risk factors for dyslipidemia, improve the health status of the service object, and delay the occurrence of dyslipidemia. This is a beneficial exploration of health management of dyslipidemia, which provides a basis for reducing the occurrence and development of chronic diseases such as dyslipidemia and reducing the cost of 
human resources. Transform the model of grassroots medical and health services, realize the contract service of general practitioners, and strengthen the network function of grassroots medical and health service, these measures can not only deepen the reform of the medical and health system, but also better safeguard people's health in the new situation. The promotion of contract services for general practitioners will gradually form a hierarchical diagnosis and treatment model of "primary-level diagnosis, two-way referral, rapid diagnosis and treatment, and linkage between upper and lower levels". With the aid of modern information technology, set up and improve the general hospital general practitioner long-term working mechanism, support the development of general practitioners in grassroots medical institutions and their team construction, improve the medical and health service capabilities and primary health management capabilities of grassroots general practitioners, sign the service contract of grassroots general practitioners. The above measures are of great significance for the establishment of the hierarchical diagnostic system.

\section{Abbreviations}

BMI: Body Mass Index; HDL-C: High-density lipoprotein cholesterol; IGPDP: Integration of general practice and personalized disease prevention in health management; LDL-C: Low-density lipoprotein cholesterol; TC: Total cholesterol; TG: Triglyceride

\section{Declarations}

\section{Ethics approval and consent to participate}

The Medical Ethical Commission of the China Medical University approved this study. The consent we obtained from study participants was written.

\section{Consent for publication}

Written informed consent for publication was obtained from all participants.

\section{Availability of data and materials}

The datasets used or analysed during the current study are available from the corresponding author on reasonable request.

\section{Conflicting interests}

All authors declare that they have no competing interests.

\section{Funding}

We gratefully acknowledge funding from the National Natural Science Foundation of China (Grant Number 71273279). Funds provided by funders help us complete data collection and analysis.

\section{Authors' Contributions}

The research was designed by XSY and RZ. It was executed by RZ, SW, YNH, BW, YW, KY, and DJQ. The first draft was prepared by RZ. XSY reviewed and helped to revise the manuscript. All authors read and approved the final manuscript.

\section{Acknowledgments}

We would like to acknowledge the collaboration and commitment of all local investigators and their staff, without whom the present study would not have been possible.

Authors' information

1. School of Public Health, China Medical University, Shenyang, China.

2. General practice department of the First Hospital of China Medical University, Shenyang, China.

\section{References}

1. Chinese Joint Committee on Revising Guidelines for the Prevention and Treatment of Dyslipidemia in Chinese Adults. Chinese Guidelines for the Prevention and Control of Dyslipidemia in Chinese Adults (2016 Revision). Chinese Journal of Circulation, 2016,31 (10): 390.

(Chinese) 
2. Pan L, Yang Z, Wu Y, Yin RX, Liao YH, et al. The prevalence, awareness, treatment and control of dyslipidemia among adults in China[J]. Atherosclerosis, 2016, 248:2-9.doi: 10.1016/j.atherosclerosis.2016.02.006.

3. Pan A, Lucas M, Sun Q, van Dam RM, Franco OH, et al. Bidirectional Association between Depression and Type 2 Diabetes in Women[J]. Archives of internal medicine, 2010, 170(21):1884.doi: 10.1001/archinternmed.2010.356.

4. Mezuk B, Eaton WW, Albrecht S, Golden SH, et al. Depression and Type 2 Diabetes Over the Lifespan: A meta-analysis[J]. Diabetes Care, 2008, 31(12):2383.doi: 10.2337/dc08-0985.

5. Berge LI, Riise T. Comorbidity between Type 2 Diabetes and Depression in the Adult Population: Directions of the Association and Its Possible Pathophysiological Mechanisms[J]. International Journal of Endocrinology, 2015,2015(443):164760.doi:

$10.1155 / 2015 / 164760$.

6. Adriaanse MC, Dekker JM, Nijpels G, Heine RJ, Snoek FJ, et al. Associations between depressive symptoms and insulin resistance: The Hoorn Study[J]. Diabetologia, 2006, 49(12):2874-7.doi: 10.1007/s00125-006-0500-4.

7. Vandorsten JP, Dodson WC, Espeland MA. National Institutes of Health consensus development conference statement: diagnosing gestational diabetes mellitus, March 4-6, 2013.[J]. Obstetrics \& Gynecology, 2013, 122(1):358-69.doi: 10.1097/A0G.0b013e31829c3e64.

8. Bellamy L, Casas JP, Hingorani AD, Williams D. Type 2 diabetes mellitus after gestational diabetes: a systematic review and metaanalysis[J]. Lancet, 2009, 373(9677):1773-1779.doi: 10.1016/S0140-6736(09)60731-5.

9. Kim C, Newton KM, Knopp RH. Gestational Diabetes and the incidence of Type 2 Diabetes: A systematic review[J]. Diabetes Care, 2002, 25(10):1862.doi: 10.2337/diacare.25.10.1862.

10. HAPO Study Cooperative Research Group, Metzger BE, Lowe LP, Dyer AR, Trimble ER, et al. Hyperglycemia and adverse pregnancy outcomes[J]. New England Journal of Medicine, 2008, 358(19):1991.doi: 10.1056/NEJMoa0707943.

\section{Tables}

Table 1 Source and grouping of research samples 


\begin{tabular}{|c|c|c|c|}
\hline District & Group & Community Health Center & Baseline Population \\
\hline \multirow[t]{8}{*}{ Dadong } & Control & Dabei & 115 \\
\hline & & Guancheng & 104 \\
\hline & & Dongzhan & 118 \\
\hline & & Wanquan & 92 \\
\hline & Test & Xiaobei & 144 \\
\hline & & Ertaizi & 136 \\
\hline & & Xiaodong & 147 \\
\hline & & Liaoshen & 120 \\
\hline \multirow[t]{6}{*}{ Heping } & Control & Taiyuan & 101 \\
\hline & & Maluwan & 277 \\
\hline & & Hunhewan & 244 \\
\hline & Test & Beishi & 107 \\
\hline & & Xita & 184 \\
\hline & & Nanzhan & 275 \\
\hline \multirow[t]{4}{*}{ Huanggu } & Control/Test & Santongqiao & $44 / 41$ \\
\hline & & Huaihe & $100 / 98$ \\
\hline & & Beita & $89 / 94$ \\
\hline & & Shouquan & $45 / 51$ \\
\hline \multirow[t]{4}{*}{ Shenhe } & Control & Daxi & 284 \\
\hline & & Nanta & 284 \\
\hline & Test & Danan & 286 \\
\hline & & Binhe & 281 \\
\hline Tiexi & Control/Test & Qigong beiyixin Village & $583 / 588$ \\
\hline \multirow[t]{2}{*}{ Subtotal } & Control & & 2480 \\
\hline & Test & & 2552 \\
\hline Total & & & 5032 \\
\hline
\end{tabular}

Table 2 Inclusion and exclusion criteria 


\begin{tabular}{|c|c|c|}
\hline Criteria & \multicolumn{2}{|c|}{ Evaluation index } \\
\hline \multirow{4}{*}{$\begin{array}{l}\text { Inclusion } \\
\text { criteria }\end{array}$} & $\begin{array}{l}\text { Biological } \\
\text { risk factors }\end{array}$ & 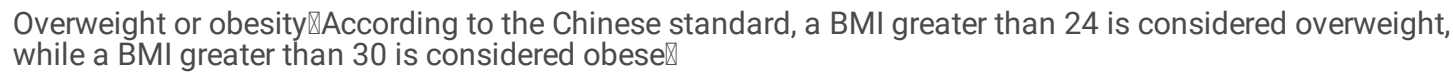 \\
\hline & $\begin{array}{l}\text { Behavioral } \\
\text { risk factors }\end{array}$ & $\begin{array}{l}\text { Current smokers (Those who have smoked continuously or cumulatively for } 6 \text { months or more in their } \\
\text { lifetime, or those who have smoked within } 30 \text { days before the visit) }\end{array}$ \\
\hline & $\begin{array}{l}\text { Unhealthy } \\
\text { diet }\end{array}$ & $\begin{array}{l}\text { The daily intake of cooking oil for each person is greater than } 30 \text { grams as the judgment standard of } \\
\text { unhealthy diet }\end{array}$ \\
\hline & Sedentary & Sit with sitting time accumulates 8 hours everyday as the judgment standard of sedentary \\
\hline \multirow{5}{*}{$\begin{array}{l}\text { Exclusion } \\
\text { criteria }\end{array}$} & \multicolumn{2}{|c|}{ Age $\geq 80$ years or $\otimes 18$ years } \\
\hline & \multicolumn{2}{|c|}{$\begin{array}{l}\text { People who have been clearly diagnosed with cardio-cerebrovascular diseases (myocardial infarction, stroke), lung cancer, } \\
\text { and chronic obstructive pulmonary disease }\end{array}$} \\
\hline & \multicolumn{2}{|c|}{$\begin{array}{l}\text { People who are unable to adhere to treatment or use other treatment methods, affecting data collection and efficacy } \\
\text { assessment }\end{array}$} \\
\hline & \multicolumn{2}{|c|}{ Pregnant or lactating women } \\
\hline & \multicolumn{2}{|c|}{ People with a genetic dyslipidemia disorder } \\
\hline
\end{tabular}

Table 3 Evaluation index system

\begin{tabular}{|c|c|c|}
\hline Aspect & \multicolumn{2}{|l|}{ Evaluation index } \\
\hline \multirow[t]{2}{*}{$\begin{array}{l}\text { Disease } \\
\text { prevention }\end{array}$} & $\begin{array}{l}\text { Behavioral } \\
\text { risk factors }\end{array}$ & Smoking; Diet; Sedentary. \\
\hline & Health literacy & A survey was conducted using the National Residents' Health Literacy Monitoring Questionnaire. \\
\hline \multirow[t]{3}{*}{$\begin{array}{l}\text { Health } \\
\text { protection }\end{array}$} & $\begin{array}{l}\text { Biological risk } \\
\text { factors }\end{array}$ & BMI \\
\hline & Risk & Dyslipidemia \\
\hline & Quality of life & A survey was conducted using the Health status SF-36 Questionnaire. \\
\hline $\begin{array}{l}\text { Health } \\
\text { promotion }\end{array}$ & $\begin{array}{l}\text { Utilization of } \\
\text { primary } \\
\text { medical } \\
\text { institutions }\end{array}$ & A survey was conducted using the Basic Health Service Needs Questionnaire. \\
\hline \multirow[t]{2}{*}{$\begin{array}{l}\text { Clinical index } \\
\text { measurement } \\
\text { methods }\end{array}$} & $\begin{array}{l}\text { Physical } \\
\text { condition and } \\
\text { routine } \\
\text { examination }\end{array}$ & $\begin{array}{l}\text { Height, weight, waist circumference (weight and waist circumference should be measured on an } \\
\text { empty stomach in the morning), blood pressure (measured with an electronic sphygmomanometer), } \\
\text { fasting blood glucose (blood glucose measured by fasting venous blood), etc. }\end{array}$ \\
\hline & $\begin{array}{l}\text { Serum lipid } \\
\text { levels }\end{array}$ & $\begin{array}{l}\text { TG,TC, LDL-C and HDL-C levels were detected in fasting venous blood.TG } \geq 1.7 \mathrm{mmol} / \mathrm{L}, \mathrm{HDL}-\mathrm{C}< \\
0.9 \mathrm{mmol} / \mathrm{L} \text { (male) or }<1.0 \mathrm{mmol} / \mathrm{L} \text { (female), } \mathrm{TC} \geq 5.2 \mathrm{mmol} / \mathrm{L}, \mathrm{LDL}-\mathrm{C}>3.4 \mathrm{mmol} / \mathrm{L} \text {, meeting one of the } \\
\text { above conditions was diagnosed as dyslipidemia. }\end{array}$ \\
\hline \multirow{4}{*}{$\begin{array}{l}\text { Specific } \\
\text { information of } \\
\text { questionnaires }\end{array}$} & \multicolumn{2}{|c|}{ Health risk assessment questionnaire } \\
\hline & \multicolumn{2}{|c|}{ National Residents' Health Literacy Monitoring Questionnaire } \\
\hline & \multicolumn{2}{|c|}{ Health status SF-36 Questionnaire } \\
\hline & \multicolumn{2}{|c|}{ Basic Health Service Demand Questionnaire } \\
\hline
\end{tabular}

Table 4 General Characteristics between the management and control groups at baseline 


\begin{tabular}{|c|c|c|}
\hline Variables & Control group $(n=2480)$ & Test group $(n=2552)$ \\
\hline \multicolumn{3}{|l|}{ Age } \\
\hline Mean $\pm S D$ & $50.2 \pm 14.0$ & $53.8 \pm 14.9$ \\
\hline Range & $18-79$ & $18-79$ \\
\hline \multicolumn{3}{|l|}{ Gender } \\
\hline Male & 1072(43.2) & $1103(43.2)$ \\
\hline Female & $1408(56.8)$ & $1449(56.8)$ \\
\hline \multicolumn{3}{|l|}{ Resident Status } \\
\hline Unmarried & $179 \llbracket 7.2 \rrbracket$ & $156 \rrbracket 6.1 \rrbracket$ \\
\hline Married & $1768 \rrbracket 71.3 \rrbracket$ & $1734 \llbracket 67.9 \rrbracket$ \\
\hline Divoiced or widowed & 196ه7.9凶 & $179 ₫ 7.0 \rrbracket$ \\
\hline Others & $337 \rrbracket 13.6 \rrbracket$ & 483ه18.9ه \\
\hline \multicolumn{3}{|l|}{ Educational Level } \\
\hline Elementary school and below & $29 \bowtie 1.2 \rrbracket$ & $35 \bigotimes 1.4 \rrbracket$ \\
\hline Junior high school & $229 \llbracket 9.2 \rrbracket$ & $425 \rrbracket 16.7 \rrbracket$ \\
\hline Senior high school & $403 \rrbracket 16.3 \rrbracket$ & $545 \rrbracket 21.4 \rrbracket$ \\
\hline Secondary school & $625 \rrbracket 25.2 \rrbracket$ & $562 \rrbracket 22.0 \rrbracket$ \\
\hline Junior college & $895 \rrbracket 36.1 \rrbracket$ & 865『33.9凶 \\
\hline University and above & $299 \rrbracket 12.1 \rrbracket$ & $120 \rrbracket 4.7 \rrbracket$ \\
\hline \multicolumn{3}{|l|}{ Nationality } \\
\hline Han nationality & $2383 \llbracket 96.1 \rrbracket$ & $2387 \rrbracket 93.5 \rrbracket$ \\
\hline Other & $97 \rrbracket 3.9 \rrbracket$ & $165 \rrbracket 6.5 \rrbracket$ \\
\hline \multicolumn{3}{|l|}{ Occupation } \\
\hline Institutional enterprise management & $184(7.4)$ & $219(8.6)$ \\
\hline Professional skill worker & $392(15.8)$ & $607(23.8)$ \\
\hline General staff & $258(10.4)$ & $260(10.2)$ \\
\hline Business/service staff & $103(4.2)$ & $158(6.2)$ \\
\hline Individual industrial and commercial households & $91(3.7)$ & $103(4.0)$ \\
\hline Non-agricultural industrial workers & $162(6.5)$ & $207(8.1)$ \\
\hline Non-labor farmers & 23(0.9) & $19(0.7)$ \\
\hline Agricultural laborer & $33(1.3)$ & $15(0.6)$ \\
\hline Retired staff & $1059(42.7)$ & $864(33.9)$ \\
\hline Student at school & $4(0.2)$ & $10(0.4)$ \\
\hline Unemployment or unemployment & $171(6.9)$ & $90(3.5)$ \\
\hline \multicolumn{3}{|l|}{ Smoking } \\
\hline Never smoked & 2068(83.4) & $1942(76.1)$ \\
\hline Quit smoking & $61(2.4)$ & $123(4.8)$ \\
\hline Smoking now & $351(14.2)$ & 487(19.1) \\
\hline Drinking & & \\
\hline
\end{tabular}




\begin{tabular}{|lll|} 
No alcohol & $2112(85.2)$ & $2010(78.8)$ \\
\hline Uninking & $368(14.8)$ & $542(21.2)$ \\
\hline Sedentary method & $1002(40.4)$ & $467(18.3)$ \\
\hline Dyslipidemia & $84(3.4)$ & $78(3.1)$ \\
\hline
\end{tabular}

Table 5. Changes in behavioral risk factors before and after intervention in different study groups

\begin{tabular}{|c|c|c|c|c|c|c|c|}
\hline \multirow{2}{*}{$\begin{array}{l}\text { Behavioral risk factors } \\
\text { Research group }\end{array}$} & & \multicolumn{2}{|c|}{ Smoking now } & \multicolumn{2}{|c|}{ Unhealthy diet } & \multicolumn{2}{|c|}{ Sedentary } \\
\hline & & $\begin{array}{l}\text { Control } \\
\text { group }\end{array}$ & $\begin{array}{l}\text { Test } \\
\text { group }\end{array}$ & $\begin{array}{l}\text { Control } \\
\text { group }\end{array}$ & $\begin{array}{l}\text { Test } \\
\text { group }\end{array}$ & $\begin{array}{l}\text { Control } \\
\text { group }\end{array}$ & $\begin{array}{l}\text { Test } \\
\text { group }\end{array}$ \\
\hline Total people & & 2480 & 2552 & 2480 & 2552 & 2480 & 2552 \\
\hline \multirow[t]{2}{*}{ Baseline } & \multirow{2}{*}{$\begin{array}{l}\text { Number of people } \\
\bigotimes \% \square\end{array}$} & 351 & 487 & 1002 & 467 & 84 & 78 \\
\hline & & $\nabla 14.2 \rrbracket$ & Q19.1凶 & $\varangle 40.4 \rrbracket$ & $\nabla 18.3 \rrbracket$ & $\otimes 3.4 \rrbracket$ & $₫ 3.1 \rrbracket$ \\
\hline \multirow[t]{2}{*}{$\begin{array}{l}\text { Comparison between } \\
\text { groups }\end{array}$} & $x^{2}$ & 22.023 & & 297.294 & & 0.441 & \\
\hline & $\mathrm{p}$ & 0.000 & & 0.000 & & 0.524 & \\
\hline \multirow[t]{2}{*}{ Intervention 12 months } & \multirow{2}{*}{$\begin{array}{l}\text { Number of people } \\
\bigotimes \% \square\end{array}$} & 265 & 367 & 469 & 434 & 51 & 91 \\
\hline & & $\otimes 10.7 \rrbracket$ & $\nabla 14.4 \rrbracket$ & Q18.9凶 & $\otimes 17.0 \bigotimes$ & 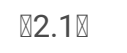 & $\otimes 3.6 \rrbracket$ \\
\hline \multirow[t]{2}{*}{$\begin{array}{l}\text { Comparison between } \\
\text { groups }\end{array}$} & $x^{2}$ & 15.640 & & 3.100 & & 10.449 & \\
\hline & $\mathrm{p}$ & 0.000 & & 0.084 & & 0.001 & \\
\hline \multirow[t]{2}{*}{ Intervention 24 months } & \multirow{2}{*}{$\begin{array}{l}\text { Number of people } \\
\rrbracket \% \bigotimes\end{array}$} & 210 & 338 & 478 & 340 & 24 & 25 \\
\hline & & $\triangle 8.5 \rrbracket$ & & Q19.3凶 & $\nabla 13.3 \rrbracket$ & 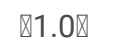 & $\otimes 1.0 \bigotimes$ \\
\hline \multirow[t]{2}{*}{$\begin{array}{l}\text { Comparison between } \\
\text { groups }\end{array}$} & $x^{2}$ & 29.573 & & 32.723 & & 0.002 & \\
\hline & $\mathrm{p}$ & 0.000 & & 0.000 & & 0.010 & \\
\hline \multirow{2}{*}{$\begin{array}{l}\text { Comparison before } \\
\text { and after intervention }\end{array}$} & $\chi^{2}$ & 41.267 & 37.203 & 388.440 & 25.056 & 34.820 & 38.787 \\
\hline & $\mathrm{P}$ & 0.000 & 0.000 & 0.000 & 0.000 & 0.000 & 0.000 \\
\hline
\end{tabular}

Table 6. Changes in health literacy levels after intervention in different study groups 


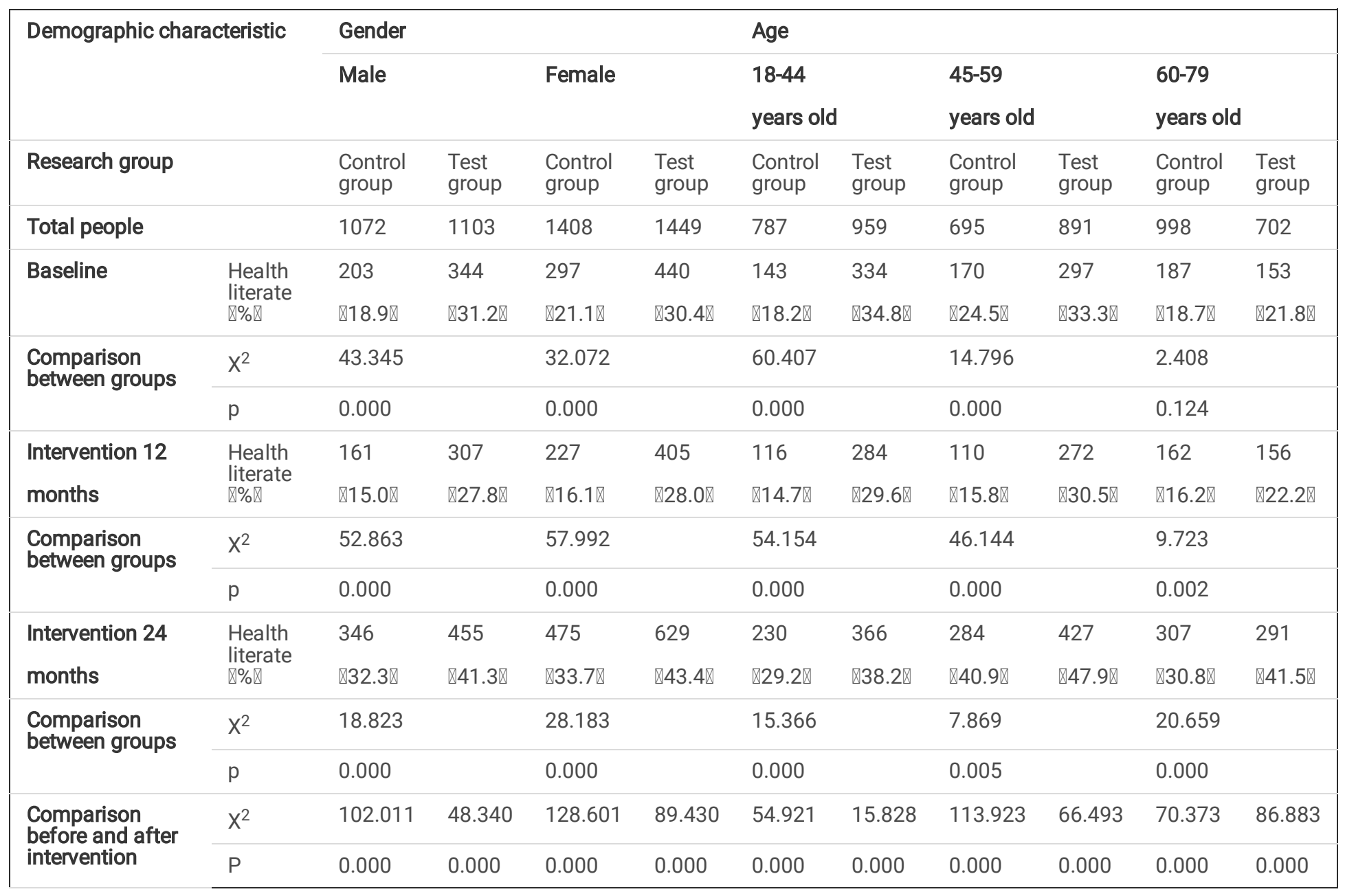

Table 7. Comparison of BMI levels in obese people in different study groups 


\begin{tabular}{|c|c|c|c|}
\hline Obesity & & BMI & \\
\hline Research group & & Control group & Test group \\
\hline Total people & & 204 & 234 \\
\hline Baseline & Blood lipid & $29.98 \pm 2.90$ & $29.95 \pm 2.45$ \\
\hline \multirow[t]{2}{*}{ Comparison between groups } & $\mathrm{t}$ & -0.100 & \\
\hline & $\mathrm{p}$ & 0.921 & \\
\hline $\begin{array}{l}\text { Intervention } 12 \\
\text { month }\end{array}$ & Blood lipid & $27.18 \pm 3.34$ & $27.96 \pm 3.17$ \\
\hline \multirow[t]{2}{*}{ Comparison between groups } & $\mathrm{t}$ & 2.507 & \\
\hline & $\mathrm{p}$ & 0.013 & \\
\hline $\begin{array}{l}\text { Intervention } 24 \\
\text { month }\end{array}$ & Blood lipid & $27.03 \pm 3.39$ & $27.77 \pm 2.83$ \\
\hline \multirow[t]{2}{*}{ Comparison between groups } & $\mathrm{t}$ & 2.480 & \\
\hline & $\mathrm{p}$ & 0.013 & \\
\hline \multirow{2}{*}{$\begin{array}{l}\text { Intervention } 12 \\
\text { month group comparison }\end{array}$} & F value & 87.966 & 60.447 \\
\hline & $P$ value & 0.000 & 0.000 \\
\hline \multirow{2}{*}{$\begin{array}{l}\text { Intervention } 24 \\
\text { month } \\
\text { group comparison }\end{array}$} & F value & 99.216 & 77.485 \\
\hline & $P$ value & 0.000 & 0.000 \\
\hline
\end{tabular}

Table 8. Comparison of blood lipid levels in people with dyslipidemia in different study groups 


\begin{tabular}{|c|c|c|c|c|c|c|c|c|c|}
\hline \multirow{2}{*}{$\begin{array}{l}\text { Blood lipid } \\
\text { Research group }\end{array}$} & & \multicolumn{2}{|l|}{ TC } & \multicolumn{2}{|l|}{ TG } & \multicolumn{2}{|l|}{ HDL-C } & \multicolumn{2}{|l|}{ LDL-C } \\
\hline & & $\begin{array}{l}\text { Control } \\
\text { group }\end{array}$ & $\begin{array}{l}\text { Test } \\
\text { group }\end{array}$ & $\begin{array}{l}\text { Control } \\
\text { group }\end{array}$ & $\begin{array}{l}\text { Test } \\
\text { group }\end{array}$ & $\begin{array}{l}\text { Control } \\
\text { group }\end{array}$ & $\begin{array}{l}\text { Test } \\
\text { group }\end{array}$ & $\begin{array}{l}\text { Control } \\
\text { group }\end{array}$ & $\begin{array}{l}\text { Test } \\
\text { group }\end{array}$ \\
\hline Total people & & 1900 & 1804 & 1900 & 1804 & 1900 & 1804 & 1900 & 1804 \\
\hline \multirow[t]{2}{*}{ Baseline } & \multirow{2}{*}{$\begin{array}{l}\text { Blood } \\
\text { lipid }\end{array}$} & 4.97 & 4.88 & 2.11 & 2.04 & 1.55 & 1.54 & 2.64 & 2.79 \\
\hline & & \pm 1.20 & \pm 1.13 & \pm 0.84 & \pm 0.80 & \pm 0.66 & \pm 0.53 & \pm 1.01 & \pm 1.07 \\
\hline \multirow{2}{*}{$\begin{array}{l}\text { Comparison between } \\
\text { groups }\end{array}$} & $\mathrm{t}$ & \multicolumn{2}{|l|}{-2.173} & \multicolumn{2}{|l|}{-2.648} & \multicolumn{2}{|l|}{-0.322} & \multicolumn{2}{|l|}{4.152} \\
\hline & $\mathrm{p}$ & \multicolumn{2}{|l|}{0.030} & \multicolumn{2}{|l|}{0.008} & \multicolumn{2}{|l|}{0.748} & \multicolumn{2}{|l|}{0.000} \\
\hline \multirow{2}{*}{$\begin{array}{l}\text { Intervention } 12 \\
\text { month }\end{array}$} & \multirow{2}{*}{$\begin{array}{l}\text { Blood } \\
\text { lipid }\end{array}$} & 4.48 & 4.62 & 1.84 & 1.88 & 1.55 & 1.58 & 2.57 & 2.76 \\
\hline & & \pm 1.28 & \pm 1.08 & \pm 0.76 & \pm 0.74 & \pm 0.59 & \pm 0.57 & \pm 0.92 & \pm 1.00 \\
\hline \multirow{2}{*}{$\begin{array}{l}\text { Comparison between } \\
\text { groups }\end{array}$} & $\mathrm{t}$ & \multicolumn{2}{|l|}{3.726} & \multicolumn{2}{|l|}{1.602} & \multicolumn{2}{|l|}{1.464} & \multicolumn{2}{|l|}{6.258} \\
\hline & $\mathrm{p}$ & \multicolumn{2}{|l|}{0.000} & \multicolumn{2}{|l|}{0.109} & \multicolumn{2}{|l|}{0.143} & \multicolumn{2}{|l|}{0.000} \\
\hline \multirow{2}{*}{$\begin{array}{l}\text { Intervention } 24 \\
\text { month }\end{array}$} & \multirow{2}{*}{$\begin{array}{l}\text { Blood } \\
\text { lipid }\end{array}$} & 4.35 & 4.62 & 1.76 & 1.87 & 1.65 & 1.60 & 2.55 & 2.76 \\
\hline & & \pm 1.19 & \pm 1.10 & \pm 0.64 & \pm 0.76 & \pm 0.67 & \pm 0.64 & \pm 0.91 & \pm 1.02 \\
\hline \multirow{2}{*}{$\begin{array}{l}\text { Comparison between } \\
\text { groups }\end{array}$} & $\mathrm{t}$ & \multicolumn{2}{|l|}{7.236} & \multicolumn{2}{|l|}{4.901} & \multicolumn{2}{|l|}{-2.431} & \multicolumn{2}{|l|}{6.665} \\
\hline & $\mathrm{p}$ & \multicolumn{2}{|l|}{0.000} & 0.000 & & 0.015 & & 0.000 & \\
\hline Intervention 12 & F value & 128.165 & 51.478 & 49.397 & 3.623 & 0.121 & 2.041 & 0.443 & 0.998 \\
\hline $\begin{array}{l}\text { month group } \\
\text { comparison }\end{array}$ & $P$ value & 0.000 & 0.000 & 0.000 & 0.057 & 0.728 & 0.153 & $0 . .506$ & 0.318 \\
\hline Intervention 24 & $\mathrm{~F}$ value & 209.596 & 54.338 & 101.045 & $11, .314$ & 23.034 & 3.734 & 5.122 & 2.489 \\
\hline $\begin{array}{l}\text { month } \\
\text { group comparison }\end{array}$ & $P$ value & 0.000 & 0.000 & 0.001 & 0.001 & 0.000 & 0.053 & 0.024 & 0.115 \\
\hline
\end{tabular}

Table 9. Changes in total scores of quality of life assessment in different study group populations 


\begin{tabular}{|c|c|c|c|c|c|c|c|c|c|c|c|}
\hline \multirow{2}{*}{\multicolumn{2}{|c|}{$\begin{array}{l}\text { Demographic } \\
\text { characteristic }\end{array}$}} & \multicolumn{4}{|l|}{ Gender } & \multicolumn{6}{|l|}{ Age } \\
\hline & & \multicolumn{2}{|l|}{ Male } & \multicolumn{2}{|l|}{ Female } & \multicolumn{2}{|l|}{$\begin{array}{l}18-44 \\
\text { years old }\end{array}$} & \multicolumn{2}{|l|}{$\begin{array}{l}45-59 \\
\text { years old }\end{array}$} & \multicolumn{2}{|c|}{$\begin{array}{l}60-79 \\
\text { years old }\end{array}$} \\
\hline \multicolumn{2}{|c|}{ Research group } & $\begin{array}{l}\text { Control } \\
\text { group }\end{array}$ & $\begin{array}{l}\text { Test } \\
\text { group }\end{array}$ & $\begin{array}{l}\text { Control } \\
\text { group }\end{array}$ & $\begin{array}{l}\text { Test } \\
\text { group }\end{array}$ & $\begin{array}{l}\text { Control } \\
\text { group }\end{array}$ & $\begin{array}{l}\text { Test } \\
\text { group }\end{array}$ & $\begin{array}{l}\text { Control } \\
\text { group }\end{array}$ & $\begin{array}{l}\text { Test } \\
\text { group }\end{array}$ & $\begin{array}{l}\text { Control } \\
\text { group }\end{array}$ & $\begin{array}{l}\text { Test } \\
\text { group }\end{array}$ \\
\hline \multicolumn{2}{|l|}{ Total people } & 1072 & 1103 & 1408 & 1449 & 787 & 959 & 695 & 891 & 998 & 702 \\
\hline \multirow[t]{2}{*}{ Baseline } & Total & 73.86 & 75.22 & 72.80 & 74.17 & 73.76 & 74.90 & 73.47 & 75.19 & 72.71 & 73.53 \\
\hline & of life & \pm 13.22 & \pm 11.11 & \pm 12.67 & \pm 11.29 & \pm 13.99 & \pm 11.61 & \pm 14.55 & \pm 10.63 & \pm 11.12 & \pm 11.36 \\
\hline \multirow{2}{*}{$\begin{array}{l}\text { Comparison } \\
\text { between } \\
\text { groups }\end{array}$} & $\mathrm{t}$ & 2.600 & & 3.022 & & 1.858 & & 2.730 & & 1.474 & \\
\hline & $\mathrm{p}$ & 0.009 & & 0.003 & & 0.063 & & 0.006 & & 0.141 & \\
\hline \multirow{2}{*}{$\begin{array}{l}\text { Intervention } \\
12 \\
\text { months }\end{array}$} & $\begin{array}{l}\text { Total } \\
\text { quality }\end{array}$ & 69.48 & 70.68 & 68.85 & 69.68 & 69.76 & 71.69 & 70.03 & 70.43 & 67.99 & 67.57 \\
\hline & of life & \pm 11.62 & \pm 10.83 & \pm 11.58 & \pm 10.93 & \pm 10.23 & \pm 9.63 & \pm 11.25 & \pm 10.77 & \pm 12.71 & \pm 12.15 \\
\hline \multirow{2}{*}{$\begin{array}{l}\text { Comparison } \\
\text { between } \\
\text { groups }\end{array}$} & $\mathrm{t}$ & 2.493 & & 1.974 & & 4.044 & & 0.711 & & -0.687 & \\
\hline & $\mathrm{p}$ & 0.013 & & 0.048 & & 0.000 & & 0.477 & & 0.492 & \\
\hline \multirow{2}{*}{$\begin{array}{l}\text { Intervention } \\
24 \\
\text { months }\end{array}$} & Total & 81.17 & 80.91 & 80.61 & 78.80 & 82.47 & 81.64 & 82.72 & 81.09 & 78.27 & 75.34 \\
\hline & of life & \pm 14.20 & \pm 17.26 & \pm 15.21 & \pm 19.41 & \pm 11.38 & \pm 15.34 & \pm 15.79 & \pm 18.39 & \pm 16.02 & \pm 21.75 \\
\hline \multirow{2}{*}{$\begin{array}{l}\text { Comparison } \\
\text { between } \\
\text { groups }\end{array}$} & $\mathrm{t}$ & -0.376 & & -2.767 & & -1.265 & & -1.870 & & -3.194 & \\
\hline & $\mathrm{p}$ & 0.707 & & 0.006 & & 0.206 & & 0.062 & & 0.001 & \\
\hline \multirow{2}{*}{$\begin{array}{l}\text { Intervention } \\
\text { for } 12 \\
\text { months } \\
\text { comparison }\end{array}$} & $\begin{array}{l}\mathrm{F} \\
\text { value }\end{array}$ & 75.188 & 104.323 & 84.227 & 136.621 & 45.705 & 45.789 & 30.537 & 104.530 & 86.876 & 104.530 \\
\hline & $\begin{array}{l}P \\
\text { value }\end{array}$ & 0.000 & 0.000 & 0.000 & 0.000 & 0.000 & 0.000 & 0.000 & 0.000 & 0.000 & 0.000 \\
\hline \multirow{2}{*}{$\begin{array}{l}\text { Intervention } \\
\text { for } 24 \\
\text { months } \\
\text { comparison }\end{array}$} & $\begin{array}{l}\mathrm{F} \\
\text { value }\end{array}$ & 167.835 & 92.980 & 230.649 & 64.688 & 211.826 & 128.488 & 138.151 & 70.397 & 84.875 & 4.119 \\
\hline & $\begin{array}{l}P \\
\text { value }\end{array}$ & 0.000 & 0.000 & 0.000 & 0.000 & 0.000 & 0.000 & 0.000 & 0.000 & 0.000 & 0.043 \\
\hline
\end{tabular}

Table 10. Comparison of the proportion of people who are willing to accept general practitioners 


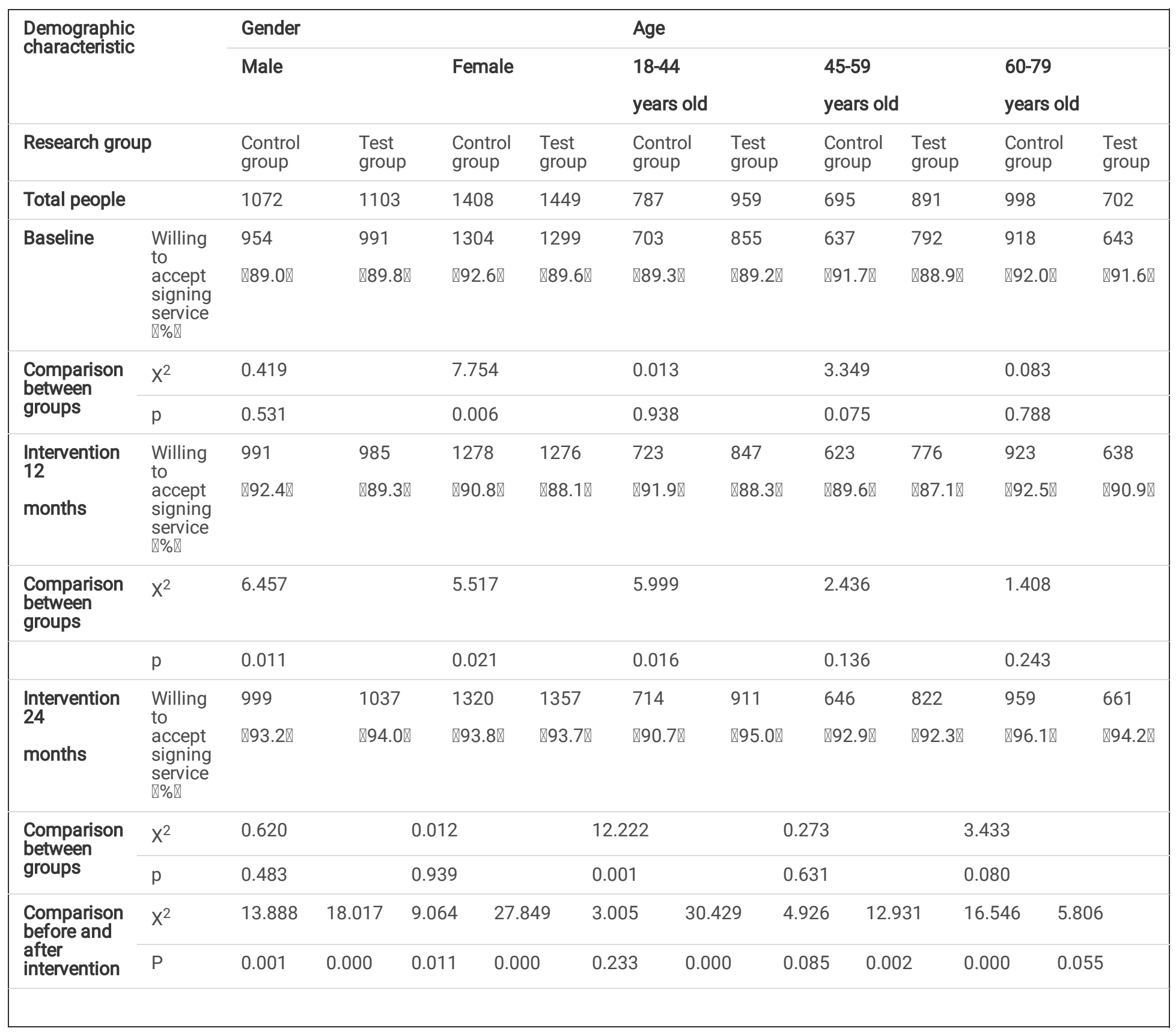

Figures 


\begin{tabular}{|c|c|c|}
\hline & $\begin{array}{l}\text { Strengthening phase } \\
\text { (2 months) }\end{array}$ & $\begin{array}{l}\text { Baseline data collection, health } \\
\text { risk assessment, establishment of } \\
\text { health intervention plan, weekly } \\
\text { follow-up }\end{array}$ \\
\hline \multirow[t]{2}{*}{$\begin{array}{l}\text { Health } \\
\text { management } \\
\text { intervention } \\
\text { cycle }\end{array}$} & $\begin{array}{l}\text { Consolidation phase } \\
\text { (1 months) }\end{array}$ & $\begin{array}{l}\text { Adjust intervention intensity } \\
\text { Change fixed behavior } \\
\text { Form active habits } \\
\text { Conduct weekly follow-up }\end{array}$ \\
\hline & $\begin{array}{l}\text { Stable phase } \\
\text { ( } 9 \text { months) }\end{array}$ & $\begin{array}{l}\text { Supervise and remind } \\
\text { follow up and monitor } \\
\text { follow up monthly } \\
\text { Evaluate intervention effect }\end{array}$ \\
\hline
\end{tabular}

Figure 1

Health management cycle. 
Individuals at high risk of dyslipidemia in community health service institutions within one month were selected as research objects in shenyang

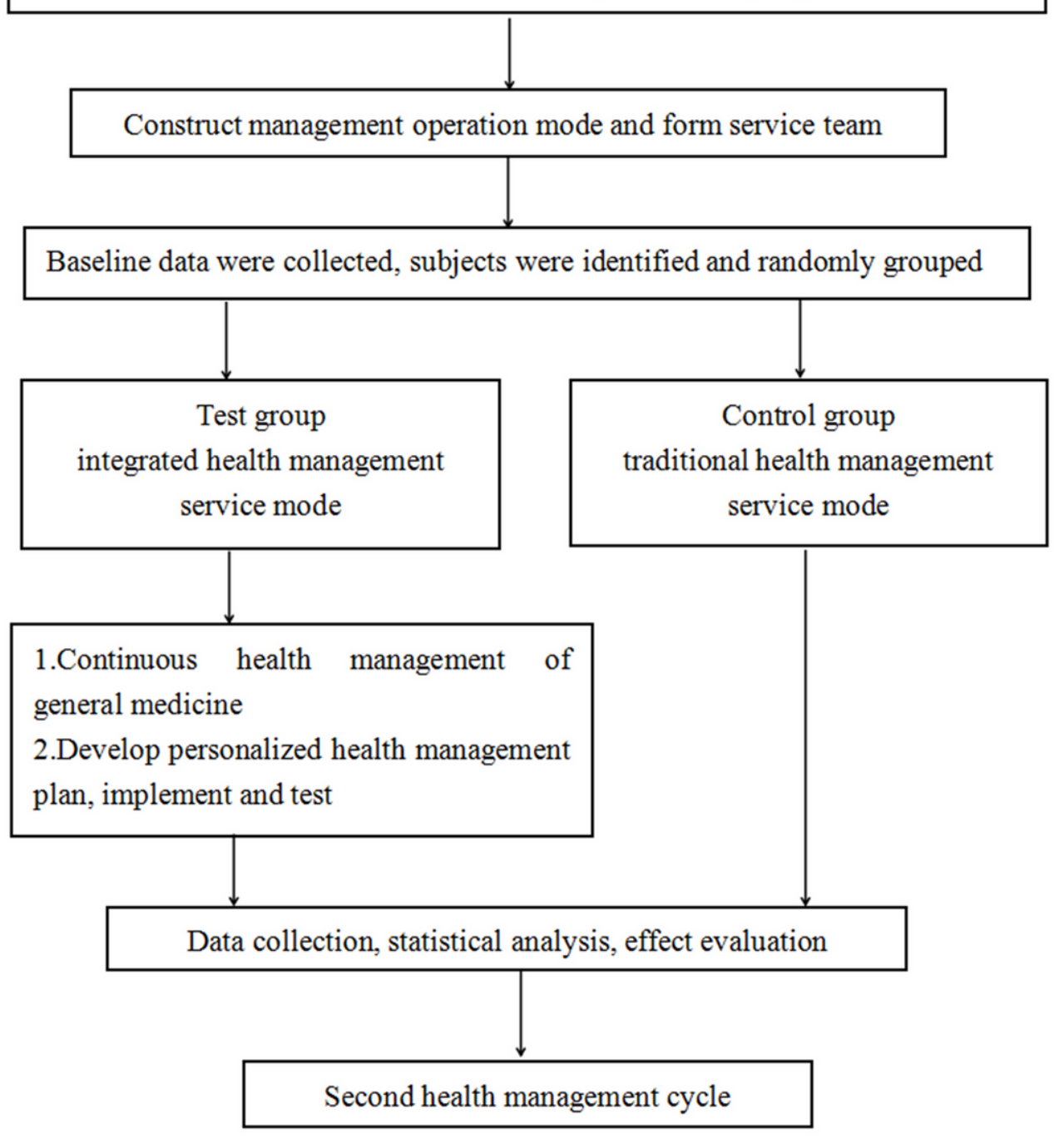

Figure 2

Technology road map. 